\title{
Case Study on Value Chain Analysis of Natural Resource Exports in Liberia
}

\author{
David M. Seward \\ School of Public Administration, Huazhong University of Science and Technology, Wuhan, China \\ Email: sewarddavid81@gmail.com
}

How to cite this paper: Seward, D. M. (2021). Case Study on Value Chain Analysis of Natural Resource Exports in Liberia. Journal of Service Science and Management, 14, 597-626.

https://doi.org/10.4236/jssm.2021.146038

Received: September 16, 2021

Accepted: December 18, 2021

Published: December 21, 2021

Copyright $\odot 2021$ by author(s) and Scientific Research Publishing Inc. This work is licensed under the Creative Commons Attribution International License (CC BY 4.0).

http://creativecommons.org/licenses/by/4.0/

(c) (i) Open Access

\begin{abstract}
Objects: Michael Porter used the term "Value Chain" in his book "Competitive Advantage: Creating and Sustaining Superior Performance" (1985). The value chain analysis describes the activities of Government performs and links them to the institution's competitive position to create jobs for Liberians, through exports. This case study research analyzes the value chain on natural resources exports in Liberia in the concessions contracts from 1847 to 2015. Methods: During the review period, the researcher has observed that Liberia has been and is currently used as a raw material country that lacks manufacturing within Liberia. Natural resources are produced outside the country. This study recommends exports of natural resources from outside the country to within Liberia, with a future focus on exportation to other end users. The research is significant to more than 5 million people in Liberia, engaging educators who want to learn more about the process and possibilities of bettering the economic condition of Liberia through the value chain and institutionally-based systems that will improve the living and job market condition of Liberia. Results: Seventy-five percent (75\%) of the Liberian population will have jobs when the Government puts a value chain system to create jobs. Conclusion: Youth under the age of 25 to 35 will have an excellent opportunity to work and have quality life/living conditions, health care and infrastructure development for the Liberian population. The lack of a value chain has caused $80 \%$ of people not to have jobs currently. The future recommendation is put forward to Liberia, which needs a future-thinking. The Government needs Ato to sign quality values chain concessions that will create jobs for its citizens.
\end{abstract}

\section{Keywords}

Value Chain, Natural Resource, Exports, Development, Sustainability, Liberia 


\section{Introduction}

Natural Resources: Iron Ore, Rubber, Timber, Diamonds, Gold, Tinand sizable deposits of Crude Oil along its Atlantic coast and land.

Agriculture: Products-Coffee, Cocoa, Sugarcane, Rice, Cassava, Palm Oil, Bananas, Plantains, Citrus, Pineapple, Sweet Potatoes, Corn, and Vegetables.

Industry: Agriculture, Iron Ore, Rubber, Forestry, Diamonds, Gold, Cement, Beverages, Construction.

Liberia is rich in natural resources. But at present, the values chain investment in natural resources on exports is outside of Liberia. It is well past time for policymakers to seek new economic strategies that will allow the shifting of the value chain in Liberia to promote economic development on natural resources exports in Liberia. The lack of attention to the internal economic development of Liberia has led to an inefficient allocation of resources that undermine efforts to strengthen state institutions and reduce unemployment of the funds available to invest in essential services to create jobs, such as health, infrastructure, and education. This situation further contributes to infrastructure and other institutions underdevelopment in Liberia. The processing of our resources outside of Liberia negatively affects the economics of Liberia. It is threatening the development process leading to the lack of employment. The 2030 vision towards economic growth and prosperity needs to focus on values chain analysis on natural resources exports in Liberia. This paper argues that a new approach is necessary for the economic development and management of natural resources. The Government's main challenges are managing the competing political and social-economic interests that arise with an influx of investment and creating a stable, enabling economic environment that will continue to attract investors' value chain in Liberia.

The Brundtland Commission Report entitled Our Common Future (1987) defined sustainable development as "development, which meets the needs of the present without concession ING the ability of future generations to meet their own needs". The 1992 United Nations Conference on the Environment and Development (UNCED), commonly referred to as the Rio Earth Summit, brought together world leaders to obtain political commitments and set a framework for definitive measures to ensure a sustainable future. The Rio Earth Summit and the resulting framework for action, the U.N. (Addison, 2003) (Ahmed \& Donovan, 1992). Sustainable Development Agenda 21, aimed to reduce economic and social disparities and address global development challenges. Agenda 21 called for increased financial support to developing countries and global commitment to implement sustainable development goals, including poverty eradication, protecting public health, and conservation and management of resources. The researcher argues that Liberia should use its natural resources to develop its own country and contribute to global communities through exports of the value chain on natural resources. Sustainable Development principles and the goals enshrined in Agenda 21 have faced challenges in implementation due partly to the 
global economic crisis and internal conflict, as is the case for Liberia. Global challenges like mitigation and adaptation to climate change, unsustainable production and consumption patterns, and food insecurity have heightened the need to renew the commitments agreed to at the 1992 Earth Summit. For Liberia, sustainable development challenges are even more poignant, increasing our susceptibility to renewed discontent and possibly internal conflict. Achieving sustainable development goals is critical to ensuring lasting peace, security, and improved quality of life for Liberians. The researcher argues that Liberia development should not be a challenge because of its small population with so many natural resources that should develop industries (Anderson, Vandervoort, Suggs, \& Clapp-Wincek, 1982) employ its citizens, build infrastructure, health care, etc.

This paper proposes a new approach to managing natural resources in Liberia and identifies the following needs:

Pro-poor focus: Given the substantial value-added relationship between growing agricultural productivity and poverty reduction, future efforts in Liberia must focus on productivity-enhancing measures with a pro-poor focus that increase incomes. Growth using traditional technologies is generally not profitable and has damaging implications for the environment. Given the low level of assets possessed by most Liberians, future efforts need to address the question of access to support (i.e. land, knowledge, and inputs) in addition to providing opportunities and an enabling environment. Liberia needs to make concerted efforts to preserve and consolidate its emerging stability by focusing interventions to ensure food security and poverty alleviation at the community and household levels, thereby improving access to food and generating sustainable activities for employment.

\subsection{Background of the Study}

The economic backwardness of Liberia is not attributable to a lack of resources or domination by foreign financial and political interests. The underlying $d$ the value-added chain of manufacturing and the processing of our natural resources currently take place outside Liberia, not allowing necessary changes to take place that would develop Liberian society. We will fight for development as sons and daughters of the land called Liberia.

This study will explore the meanings of the terms government, economy and informative development to understand those features that may link them together (Johnston, 1906). Ultimately, understanding the interplay between these forces may enable the Government to set economic, education, and healthcare policies to enhance Liberia's development. The study investigated popular and scholarly sources on Government and education towards a better understanding of the hypothesis.

Using available information of contracts signed by past and present government economic systems in Liberia, a model will be constructing to determine if the hypothesis has a basis in measuring the information. The high unemploy- 
ment rates reflect poorly on the Government of Liberia, which has been and continues to look like evil to the people of Liberia. The current system is not fulfilling the proper governing of its people when it comes to economic development. We must consider how the values chain on natural resources shift to this form of economic growth and be maximized concerning the changes in the developmental trends of the world, realizing the economic realities, moving of peoples and technological advancements for which the Liberia governmental system is no exemption. Underdevelopment is common in African countries, which continues to be the universal result of a flawed system among African nations. The researcher aims to find how the impact of bad systemic Government in Liberia relates to public funds that lack a focus on nationality.

\subsection{Literature Reviews}

In this chapter, the study uses the term "natural resources for economic development in Liberia" (NRFEDIL) as the set of strategies to improve economic development in Liberia (August 222011 An Act to Ratify the Concession Agreement). It includes private companies manufacturing during the exploration, contracting, and extraction and allocating the value chain on natural resources in Liberia. The full scope of "natural resources" should include the following sectors: agriculture, rubber, food crop, tree crop, mining minerals and metals, fish, land, and water; however, in this study, the chosen initiatives have a bias towards the economic development of Liberia in nonrenewable resources: minerals and metals. Michael Porter used the term "Value Chain" in his book "Competitive Advantage: Creating and Sustaining Superior Performance" (1985). The value chain analysis describes the organization's activities and links them to its competitive position.

It is not to ignore the importance of managing fisheries, land or water, which the specialized Literature has well documented. Yet, over the past decade, there has been an increase of "resources management" initiatives that started with the creation of the Kimberly Process Certification Scheme (KPCS) and continued with the Global Witness-Publish What You Pay Coalition (PWYP) and the Extractive Industries Transparency Initiative (EITI).

Other organizations, including many bilateral and multilateral donors, have geared their efforts to improve the management of natural resources in Liberia in the direction of agriculture and minerals. The management of these sectors is perhaps a unique case of a traditional "natural resource" viewed through the lens. It has been incorporating as one key sector under the Liberia EITI. This study develops in stages. The first part discusses what is generally understood as N.R. in the extractive industry, looking at specific definitions and interpretations of what we understood as successful. A significant issue here is to differentiate whether they are conceiving to further achieve economic development in Liberia-for example, signing contract concessions that ensure economic growth and promote greater civil society participation. In providing the means to obtain improved social outcomes, this reviewer argues that most of the efforts and as- 
sociated impact evaluations have more to say regarding the nature of evidence to shifting production in Liberia to impact improved development outcomes. The second part reviews and discusses existing knowledge regarding theories of change in managing the natural resource shifting value chain within Liberia. The discussion centres on two issues: the intervening factors that are perceiving as key to producing the desired change and when the difference takes place when Liberia begins manufacturing the natural resources within Liberia. The third part of this study looks at existing approaches and methodological challenges for measuring practical impact, including new strategic methods.

\subsection{Purpose of the Study}

The research focuses on analyzing the value chain on natural resources exports in Liberia for economic benefits; need to educate the people of Liberia on the importance of value chain to the Country natural resources shifting production from outside to produce within the country. Liberians must plan to transform subsistence agriculture to commercial farming, educate and train young people to acquire skills following development needs, and specify those conditions under which foreign firms are to operate to yield developmental effects for the country. In a word, there must be a conscious strategy for development based on knowledge of the current economic structure and performance. There must be a keen knowledge of financial processes to manufacture and implement development policies. The upper levels of Government must be sufficiently honest, sufficiently competent, and concerned with national economic development. These conditions are absent in Liberia. There is neither sufficient honesty nor concern with national development to understand why and how this is so. One must realize Liberia's past political and social organization, which, in turn, requires an understanding of Liberian history. The past structures and policies which prevent development are the unreformed, traditional structures and policies carried into the current economic environment of massive iron-ore mines and rubber plantations.

When Americo Liberians speak of the "nation", they mean themselves. The Americo Liberians do not yearn to transform society. In Liberia, political form differs radically from the political substance, and official pronouncement differs radically from actual practice. Natural resources found in Liberia include iron ore, diamonds, gold, and water. Liberia has five significant iron ore deposits, Bomi Hills, Mano River, Mt. Nimba South, Tokadeh, and Bong mines

1) To encourage more reform in all sectors with new economic policy.

2) To highlight the system's poorly equipped nature to encourage the administration to improve new policy.

3) Encourage capacities building in all sectors.

4) Encourage university students to change their area of study for economic development expansion.

5) Determine the extent to which our human resource needs to be equippe to adequately serve the need of Liberia and advance recommendations on the way 
forward.

\subsection{The Importance of the Study}

This study is essential, giving even life to the people of Liberia trade observation and concessions signed by the Government of Liberia from 1926 until the present, illustrating the lack of economic benefit to the people of Liberia. The research study design was use to reading the information from 1926 to 2015 from international reports on Liberia and evaluate natural resources within the Liberia System spread across local districts throughout Liberia. This study focuses on Liberia and covers Liberia's natural resources exports in Liberia, analyzing Liberia's economic condition. Hopefully, into programs as they shape and shape each other. Such a model has implications for the structure, staff role, selection of policymakers, and evaluation methods. More importantly, the educational philosophy must warrant learning as being life-long.

\subsection{Overview of Liberia Economic}

Under President Tubman's, the "open-door policy" has been the most dramatic change; the result has been growth in primary production and the accumulation of new buildings, roads, and other social capital reflected in the national income accounts. But Europeans cannot become citizens or own land in Liberia. They are contractual guests-resident aliens who take no part in political life (August 222011 An Act to Ratify the Concession Agreement). From 1950 to 1962, Liberia had a high growth rate due to heavy foreign investment in iron ore and rubber, but it remains undeveloped mainly otherwise. American and European investments affect Liberian development in two principal ways.

The wage bill grows absolutely as the number of Liberian wage labourers grows. The wage-earning labour force more than doubled between 1950 and 1960. But the increased effective demand due to higher wage incomes has not induced enlarged domestic production of goods bought by wage earners; it has increased imports.

Government incomes grew eightfold between 1950 and 1960, and the total of external borrowing by the Government grew from almost zero to $\$ 100$ million.

The growth rates of the G.D.P. in the 1950s and 1960s averaged 9\%. The 70\% of Liberians in the non-monetized sector, mainly subsistence farmers, survived on per capital incomes of U.S.C. \$50, compared with a national average of US $\$ 270$ C. Various analyses of the economic prospects of the 1970s and 1980s highlighted the economic benefits that would accrue from a more integrated Liberian economy. Joseph Saye Guannu. Liberian history up to 1847. The persistence of this dualistic structure has been identified as a significant contributing factor to the subsequent conflict. The impact of the civil war and poor governance has been devastating for Liberia's economic development. Before the war, aggregate financial performance was impressive. Between 1955 and 1965, foreign investment increased from US\$60 million to US\$500 million, three-fifths of which 
was invested in the mining sector. The 1970s heralded a new era of low growth: by the first half of 1970, annual G.D.P. growth fell to $1 \%$ and was negative by middecade. The coup of 1980 initiated a sustained period of economic decline in which G.D.P. dropped precipitously from over US $\$ 1.14$ billion in 1987 to a mere US $\$ 260$ million in 1997. Despite a slight recovery early this century, G.D.P. today remains less than half of that in the 1970s.

Figures 1-6 explain Liberia's natural resources without value-added due to the lack of value on the natural resources; unemployment is very high in Liberia; the economy is not growing, and development is slow.

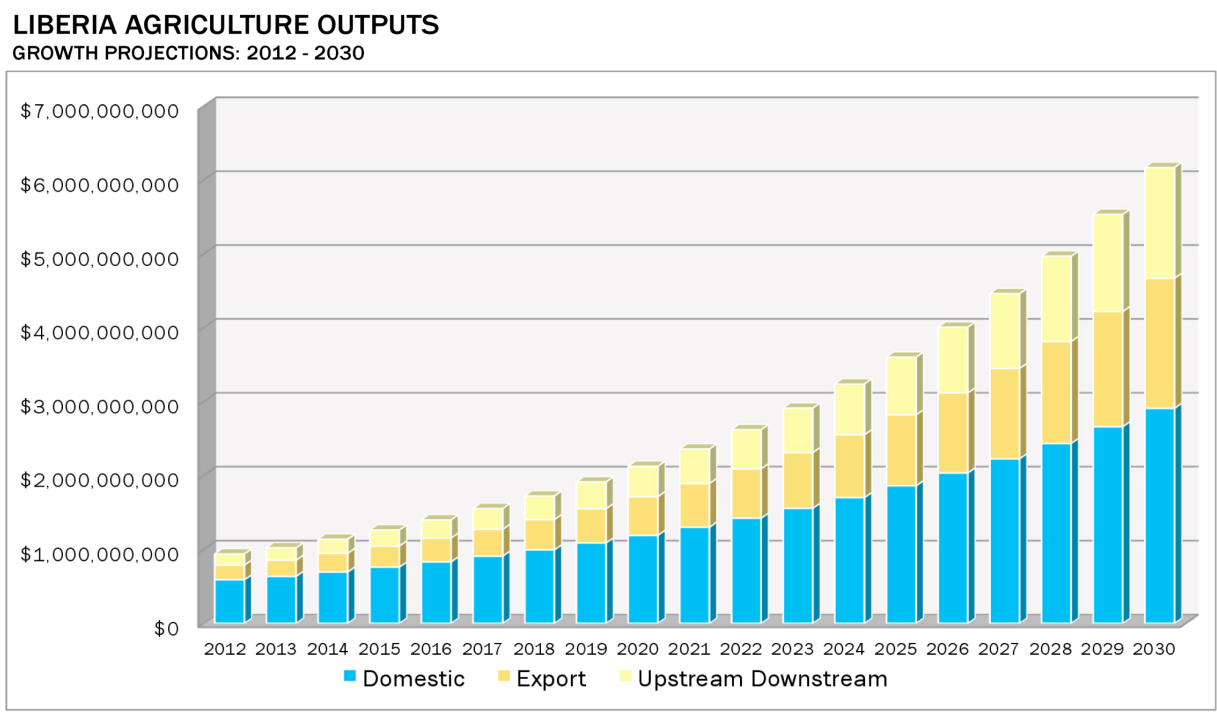

Figure 1. Valude added to agriculture product before 2030 could help economy growth.

\section{ALTERNATIVE GROWTH MODEL}

\section{BASED ON MCKINSEY LIONS METHODOLOGY}

\begin{tabular}{lrr}
\hline McKinsey Growth Estimates $\mathbf{2 0 3 0}$ & Liberia Subregion & Liberia \\
Base Growth & $\$ 18,519,673,213$ & $\$ 1,293,444,567$ \\
$\quad$ Additional Land & $\$ 10,000,000,000$ & $\$ 698,416,517$ \\
$\quad$ Yield Gains & $\$ 24,000,000,000$ & $\$ 1,676,199,642$ \\
$\quad$ Higher value crops & $\$ 12,000,000,000$ & $\$ 838,099,821$ \\
Green Revolution Gains & $\$ 46,000,000,000$ & $\$ 3,212,715,980$ \\
2030 Annual Revenue Projections & $\$ 64,519,673,213$ & $\$ 4,506,160,546$ \\
\hline Total Annualized Growth & & $6 \%$ \\
\hline
\end{tabular}

Liberia Estimates under this model derived from McKinsey Green Revolution growth assumptions for Africa at large (see below)

An African "green revolution" could raise agricultural production to $\$ 880$ billion per annum by 2030

Africa agricultural production revenue

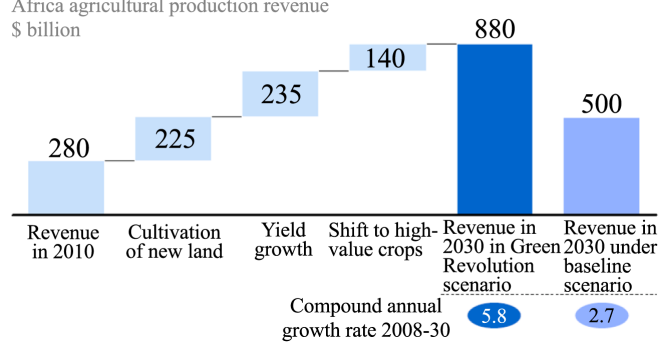

Figure 2. If only value is added, this growth model would meet revenue projections for the government and its people. 


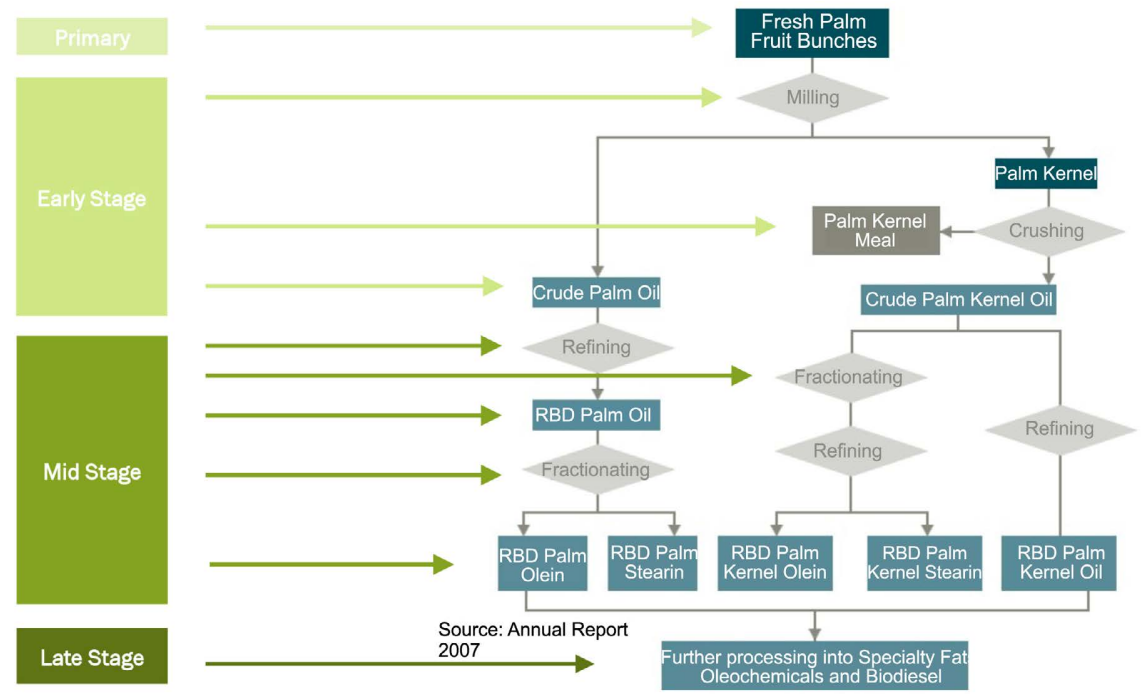

Figure 3. The palm oil have so much in inpart on our daily living in Liberia, we need more value on its.

\section{PALM OIL}

\begin{tabular}{|c|c|c|c|c|c|c|}
\hline Rank & Area & Item & Unit (000's) & 2008 & 2009 & 2010 \\
\hline 1 & Western Africa & Cocoa beans & $\$$ & $3,507,865$ & $4,607,819$ & $4,239,990$ \\
\hline 3 & Western Africa & Rubber Nat Dry & $\$$ & 672,747 & 514,064 & $1,001,251$ \\
\hline 4 & Western Africa & Cocoa Paste & $\$$ & 445,009 & 489,026 & 610,368 \\
\hline 2 & Western Africa & Cotton lint & $\$$ & 716,728 & 553,543 & 591,701 \\
\hline 6 & Western Africa & Palm oil & $\$$ & 409,961 & 397,413 & 450,131 \\
\hline 5 & Western Africa & Cocoa Butter & $\$$ & 380,176 & 430,524 & 433,307 \\
\hline 7 & Western Africa & Cashew nuts, with shell & $\$$ & 422,208 & 324,891 & 298,499 \\
\hline 8 & Western Africa & Coffee, green & $\$$ & 164,603 & 153,240 & 203,527 \\
\hline
\end{tabular}

\begin{tabular}{|l|c|c|}
\hline Liberia Palm Oil Potential & Unit & Value \\
\hline Average Oil Palm Productivity & Tonnes / Ha & 7.54 \\
\hline Palm Oil Land Under Cultivation Addition & Ha / Year & 10,000 \\
\hline Liberia Oil Current Palm Oil Land & Ha & 17,000 \\
\hline Current potential export \$ /year & $\$$ & $\$ 15,640,000$ \\
\hline 2030 potential export \$ /year & $\$$ & $\$ 205,120,000$ \\
\hline
\end{tabular}

Figure 4. The palm oil sector have a greater future if value is added for export.

\begin{tabular}{|c|c|c|}
\hline Liberia Total Timber Market - Commodity Based & Units & Value \\
\hline Total Liberia timber region* & $\mathrm{Ha}$ & $4,300,000$ \\
\hline Granted timber concessions & $\mathrm{Ha}$ & $2,400,000$ \\
\hline Non-concession timber region & $\mathrm{Ha}$ & $1,900,000$ \\
\hline Sustainable timber extraction ratio** & $\mathrm{m}^{3} / \mathrm{Ha}$ & 0.22 \\
\hline Total sustainable timber extraction potential (per annum) & $\mathrm{m}^{3}$ & 946,000 \\
\hline Sawn timber price $/ \mathrm{m}^{3}$ & \$usd & $\$ 152$ \\
\hline Total annual extractable timber (commodity value) & $\$$ usd & $\$ 143,792,000$ \\
\hline \multicolumn{3}{|l|}{$\begin{array}{l}\text { * LIBERIA INVESTMENT OFFICE } \\
\text { **GROWING FOREST PARTNERS ANALYSIS }\end{array}$} \\
\hline \multicolumn{3}{|l|}{ Liberia Current Estimated Timber Extraction } \\
\hline Current timber harvest value* & $\$$ usd & $\$ 80,256,000$ \\
\hline \multicolumn{3}{|c|}{ BASED ON CURRENT ALLOCATED TIMBER CONCESSION S OF 2.4MM HA. AT SAWN TIMBER PRICE } \\
\hline \multicolumn{3}{|l|}{ Value Add Scenario } \\
\hline Ghana value added plywood market price & $\$$ usd & $\$ 381$ \\
\hline Conversion to value added goods ( $15 \%$ total market) & $\mathrm{m}^{3}$ & 141,900 \\
\hline Market estimate w $15 \%$ value-added Eports & & $\$ 54,063,900$ \\
\hline Combined timber and value added products market & \$ usd & $\$ 176,287,100$ \\
\hline
\end{tabular}

Figure 5. The timber sector of Liberia has no value added, if value is added we could benefit more. 


\section{LIBERIA \& REGION RESOURCE SECTOR VALUE CHAIN ${ }^{1}$ SUMMARY}

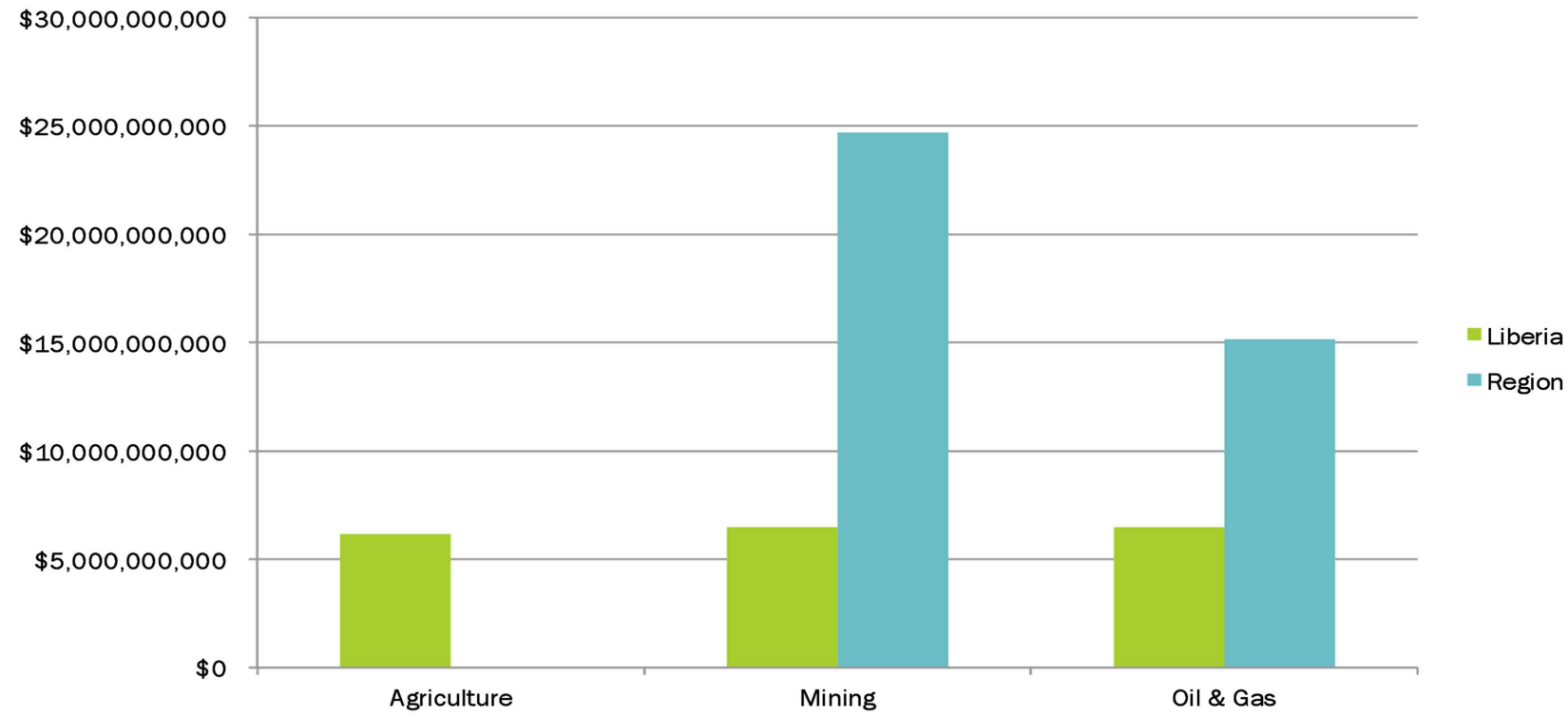

${ }^{1}$ Represents total value chain, not value chain that could be realistically captured. Further analysis must be conducted to better estimate Which portions could be captured based on feasibility, location, comparative advantages, and competitive analysis.

Note on Agriculture: Regional Value Chain for Agriculture not computed since agricultural value chains reside in country and thus unable to be captured

Figure 6. These sectors need value added for jobs, growth and development.

\section{Natural Resources Exports in Liberia}

\subsection{Natural Resource Exports in Agricultural Sectors}

Agriculture is the predominant Source of livelihood for over $70 \%$ of the population. The sector included two main outcome objectives: 1) Increased sales and shipments of agricultural production to urban and export markets; and 2) (August 222011 An Act to Ratify the Concession Agreement) Increased agricultural production of food supply to rural families-improved subsistence farming. We needed more success in the agriculture sector during 1960-70 that centred on providing technical and material inputs to farmers to stimulate increased production. Two of the most important agricultural commodities in Liberia are oil palm and rubber. Foreign investment in this sector has increased with the reemergence of significant commercial agricultural concessions. Smallholder subsistence agriculture and fisheries, directly and indirectly, is the main economic activity for a majority of the population. Although Liberia's agricultural sector has made significant gains, many challenges remain. Sustainability of the agricultural industry requires an integrated approach to resource use, including innovative farming practices, conservation of critical wildlife habitat, and sound land use planning.

Agriculture: Products-coffee, cocoa, sugarcane, rice, cassava, palm oil, bananas, plantains, citrus, pineapple, sweet potatoes, corn, and vegetables. Agriculture concessions fall under the definition of Section 73-1 of the Public Procurement and Concession Act (PPCA), according to which the Government grants 
the right to develop and operate the agricultural plantation provided that the private entities are responsible and bear the risks of capital investment to working and other costs of the project. In the Materiality Report, the Materiality Report indicates that the Government of Liberia granted the following companies rights during the period under review: Cavalla Rubber Corporation, Maryland Oil Palm/Decoris and Golden Veroleum, Sinoe Rubber Corporation, Firestone Tire and Rubber Company and Guthrie Rubber Plantation that the contract should form part of the review process and informed accordingly. Therefore, the amended list of those contracts retained for audit in the Previous studies had suggested that "the development of agricultural land such as swamp is the key to producing a marketable surplus". Nevertheless, the (overall, negative) experiences of previous agricultural development projects that encouraged swamp rice production provide several helpful lessons, and tremendous challenges remain.

1) Land ownership: Many swamp developments are communally owning, and individuals do not have identifiable plots but are allotted actions annually, according to need and past stewardship. It does not encourage the farmer to invest in land improvement.

2) Food security: To be fair, swamps developed with development funds have provided land for the most significant number, resulting in only a few plots per family. The properties allocated to each family are insufficient to meet their food requirements and therefore necessitate developing an upland farm to ensure food security.

3) Maintenance: The primary work of upland farming island preparation (the current crop). The major work in swamp rice production contributes to maintaining "communal" structures (i.e., ensuring future crops). The social change from "making your own farm" (working for today) to a Communally maintained farm "investing for tomorrow" is challenging and assumes a natural tendency for cooperation that does not usually extend beyond the extended family.

4) Timeliness and sensitivity of operations: This is more critical in swamp rice production than upland production. In particular, the essential factors are weeding and irrigation.

Agricultural Sector was as follows:

\subsubsection{Tree Crops, Coffee and Cocoa}

Tree crops to ensure income generation and sustainable livelihoods in Liberia cocoa sub-sectors (Boley, 1983; Block \& Timmer, 1994). Agriculture has long influenced the performance of the Liberian economy, especially of livelihoods. In fact, since the mid-nineteenth century, when coffee was introducing in Liberia, tree crops and natural resources such as timber, iron ore, other minerals have driven growth and economic development. Table 1 shows the numbers of companies in the agriculture sector, time without adding value and is very sensitive in operations in growing the Liberian economy with value-added production. 
Table 1. Agricultural sector companies and location in Liberia.

\begin{tabular}{|c|c|c|c|c|}
\hline Company & Date approved & Date printed & $\begin{array}{l}\text { Duration } \\
\text { (years) }\end{array}$ & Location \\
\hline $\begin{array}{l}\text { Firestone Tire } \\
\text { and Rubber company }\end{array}$ & October 2, 1926 & October 10,1926 & $99+35$ & $\begin{array}{l}\text { Harbel, } \\
\text { Margibi }\end{array}$ \\
\hline $\begin{array}{l}\text { Cavalla Rubber } \\
\text { Corporation }\end{array}$ & August 2, 2011 & August 17, 2011 & 50 & Maryland \\
\hline $\begin{array}{l}\text { Golden Veroleum } \\
\text { (Liberia) Inc. }\end{array}$ & September 1, 2010 & September 2, 2010 & 65 & Multiple \\
\hline $\begin{array}{l}\text { Maryland Palm } \\
\text { Oil/Decoris }\end{array}$ & August 2, 2011 & August 17, 2011 & 33 & Maryland \\
\hline $\begin{array}{l}\text { Sime Darby } \\
\text { Plantation } \\
\text { (Liberia) Inc. }\end{array}$ & July 23, 2009 & July 29, 2009 & 63 & Multiple \\
\hline $\begin{array}{c}\text { Cocopa } \\
\text { Plantation }\end{array}$ & January 7, 1949 & January 18, 1949 & 40 & Nimba \\
\hline $\begin{array}{l}\text { Sinoe Rubber } \\
\text { Corporation }\end{array}$ & June 5,1953 & June 19, 1953 & 80 & Sinoe \\
\hline $\begin{array}{l}\text { Guthrie Rubber } \\
\text { Plantation }\end{array}$ & May 4, 1963 & May 11, 1963 & 45 & Bomi \\
\hline
\end{tabular}

\subsubsection{Rubber}

Agreements approver at that time. Firestone obtained a ninety-nine (99) year lease on a million acres of land suitable for producing rubber and other agricultural products. At the same time, Firestone made a loan of $\$ 2,500,000$ to the Liberian Government. Under the terms of the provision of the financial agreement, Firestone acquired control over the revenues of the Government. In recent years, however, Firestone has not had the same dominant position concerning Liberian finances. The Firestone Company has two rubber plantations in actual operation with a combined operating concession of 80,000 acres, the plantations that produce $90 \%$ of the rubber output in the country. The significance of Firestone's relationship to the whole economy can be seen, in part, in the fact that the annual value of Liberia's yearly exports is in the neighbourhood of $\$ 55,000,000$, with rubber accounting for more than $\$ 45,000,000$ of this amount (Block \& Timmer, 1994; Bravo-Ortega \& Lederman, 2005; Barrett, Reardon, \& Webb, 2001). The Firestone Plantation Company (located in Harbel, Margibi County) was granted a 99-year concession for one million acres (approximately 416,670 ha) in 1926. Initially, the company was subject to a land tax of 6 cents per acre and Liberian corporate income tax (a maximum of $45 \%$ of net profits). The Firestone is at present owned by Bridgestone. The National Transitional Government of Liberia (NTGL) renewed the concession agreement in 2005. Lawmakers reviewed this agreement in 2006. In 1996, LIBCO sublet the management of the plantation 
to a Liberian company owned by the then Minister of Agriculture Roland Massaquoi. In January 2007, the Government suspended the agreement citing poor governance.

Goodrich was granted tax exemption up to 1973 and then paid corporate tax at a rate of $25 \%$ of net profits for the next ten years, after which the company paid the then regular corporate tax rate. In 1981 the plantation was taken over by the Government following the military coup, and the Guthrie Rubber Company of Malaysia negotiated a management contract with the Government. Agro Resources Corporation Liberia Ltd. in 2005. The plantation is currently under interim management. The Salala Rubber Corporation in Bong County (40,000 ha) was established in 1959 by the Liberian Agriculture Corporation (L.A.C.). The the 70-year lease for 125,000 ha in Grand Bassa County was signed in 1959, initially by a construction company to whom the Government was indebted, and then sold to Uniroyal. The second-largest plantation, a processing plant for producing latex for export, was installed in 1968. The plantation was ransackedin 1989. In 1998 a Luxemburg company, Socfinco, bought the leasehold rights to L.A.C. and Weala. Table 2 explains the low contribution of agriculture products to G.D.P. of Liberia.

\subsection{Nature Resource Exports in Mining Sector}

The Ministry of Lands, Mines and Energy (MLME) is the Government agency responsible for administering the mining sector and has oversight of energy, land, mineral, and water sectors. The mineral sector is regulating by the Mining and Minerals Law of 2000. The new Mineral Policy of Liberia became effective on March 1, 2010. Mining rights are grouping into the following categories, with annual renewal required for continued operations:

1) Prospecting (\$125);

2) Class $C(\$ 150)$;

3) Class B $(\$ 10,000)$;

4) Gold Brokers (\$1500);

5) Diamond Brokers ( $\$ 1500)$;

6) Gold Dealers ( $\$ 5000)$;

7) Diamond Dealers $(\$ 25,000)$;

Table 2. Sector composition of GDP percentages.

\begin{tabular}{|c|c|c|c|c|c|c|c|c|c|}
\hline Years & 1978 & 1979 & 1980 & 1987 & 1988 & 1989 & 2003 & 2004 & 2005 \\
\hline Agriculture & $11 \%$ & $10 \%$ & $11 \%$ & $33 \%$ & $28 \%$ & $34 \%$ & $46 \%$ & $52 \%$ & $52 \%$ \\
\hline Rubber & $6 \%$ & $5 \%$ & $6 \%$ & $7 \%$ & $5 \%$ & $7 \%$ & $11 \%$ & $20 \%$ & $21 \%$ \\
\hline $\begin{array}{c}\text { Coffee } \\
\text { and cocoa }\end{array}$ & $-1-$ & $-/-$ & $-1-$ & $1 \%$ & $1 \%$ & $1 \%$ & $0 \%$ & $0 \%$ & $0 \%$ \\
\hline Rice & $0 \%$ & $0 \%$ & $0 \%$ & $10 \%$ & $9 \%$ & $10 \%$ & $6 \%$ & $5 \%$ & $6 \%$ \\
\hline
\end{tabular}

Source: C World Bank (1982) C, UNDP (2001) and I.M.F. (various years). 
8) Reconnaissance $(\$ 15,000)$;

9) Exploration ( $\$ 5000$ plus surface rental);

10) Mineral Development Agreement (M.D.A.);

11) Class A $(\$ 50,000)$.

\subsubsection{Iron Ore}

Liberia, Africa's largest iron ore exporter, the Liberia Mining Company was the first of four iron ore companies that produced and shipped large quantities of iron ore. In the 1960s and 1970s, Liberia became Africa's largest iron ore exporter and third on the world list of iron ore exporters. In 1958, a concession agreement with the National Iron Ore Company (NIOC) to exploit the Mano river iron ore deposits followed. The Liberian American Swedish Minerals Company (LAMCO)'s Joint venture, which became operational in 1960/1961, exploited the rich Nimba mountains iron ore deposits. The investments within the LAMCO the Joint venture was the most significant Swedish investment abroad after 1945. The fourth mining company, Bong Mining Company (B.M.C.), was created following a concession agreement with German investors in 1958. The mine opened in 1965. "Bong mine" as the company was, and still is, called in Liberia, was then the most prominent German investment. Today we have the China Union operating in Liberia within Sub-Sahara Africa. We now call the place "Bomi Hills becomes Bomiholes". In 1977, L.M.C., Liberia’s first iron ore mine, closed its doors. The ore deposits at Bomi hills had been depleting. During the 1951-1977 period, L.M.C. had shipped the U.S. \$540 million worth of iron ore.

In contrast, during that time (27 years), the Liberian Government received some U.S. \$84 million (excluding rentals), or approximately $16 \%$ of L.M.C.'s sales income. In 2010, Liberia did not produce iron ore but did export stockpiled material. In September 2010, the Government granted O. A. O. Severstal (61.5\%) and African Aura (38.5\%) permission for the Putu iron ore project. The 25-year agreement provides for the construction and development of the project. Receipts from the export of stockpiled iron ore also rose to $\$ 2.4$ million from $\$ 900,000$ in 2009. Liberia's exports to the United States were valued at about $\$ 180$ million in 2010 compared with about $\$ 80$ million in 2009 and $\$ 143$ million in 2008; rough diamond accounted for $\$ 555,000$ of these exports. Imports from the United States were valued at about \$190 million in 2010 compared with \$95 million in 2009 and $\$ 157$ million in 2008. These included nearly $\$ 8$ million worth of railway transportation equipment, $\$ 6$ million worth of specialized mining equipment, and \$2 million worth of excavating machinery. The estimated proceeds from Liberia's total exports in 2010 increased by $50 \%$ to $\$ 223$ million compared with $\$ 149$ million in 2009. The increase is attributing to the increased demand for primary commodities in response to the global economy. In 2010, Arcelor Mittal and B.H.P. Billiton Ltd. of Australia announced that they had ended a preliminary discussion to. 


\subsubsection{Gold}

African Aura held a $100 \%$ interest in the New Liberty Gold (N.L.G.) deposit, which is locating about 90 kilometres $(\mathrm{km})$ north of the capital city of Monrovia. In July, the Government granted the company a Class " $A$ " mining license to explore and mine a total area of 457 square kilometres $\left(\mathrm{km}^{2}\right)$. A definitive feasibility study was to be complete in the fourth quarter of 2011. The New Liberty Gold Mine was expecting to produce about 3100 kilograms per year of gold; earnings from the gold sector increased by $29 \%$ to $\$ 15.3$ million from $\$ 11.9$ million in 2009. Some traffickers are snuggling up to $10 \mathrm{~kg}$ of gold per week through Côte d'Ivoire and Guinea. It is smelted into bullion and then trafficked to the United Arab Emirates; it was on the international market. Most of this trade is controlling by Mandingo and Fulani traders who repatriate capital through informal banking mechanisms. Liberian gold is also reported to be highly pure, with only a negligible 3 per cent of mass lost during the smelting process. This study reveals that most gold production takes place in south-eastern Liberia, particularly in Grand Gedeh, River Gee and Sinoe counties; there exits significant activity in the Gold Forest region of Grand Cape Mount County, which is adjacent to the Sierra Leonean border.

\subsubsection{Diamond}

In June 2009, Fundy Minerals Ltd. of Canada announced that 12 new primary diamond and gold targets were identified at Sehnkewen Cestos with the potential of intrusions and dykes. The company obtained a mineral exploration license for the claim in August 2008. In April 2010, Fundy announced that it would write off its Liberia operations by 2011 and focus on exploration in Canada instead. Export receipts from minerals also increased during the year. Earnings from the diamond sector increased by $70 \%$ to $\$ 11.9$ million from $\$ 7$ million in 2009.

\subsection{Natural Resource Exports in Forestry Sector}

Liberia has $40 \%$ of West Africa's rainforest. Liberia is a West African coastal nation blanketed by rich tropical forests that support its economy, ecology, and society. The country contains more than $40 \%$ of the remaining Upper Guinean Forest, a vibrant ecosystem and Forests are also essential sources of non-timber products such as meat, fish, medicines, and resins, used for livelihoods and subsistence (Concession Agreement between the Government of Liberia and the Maryland Oil Palm Plantation August 2, 2011; Columbia University Press, 1961; Cassell, 1970). Liberia has a land area of 11.1 million hectares and a population of 3.3 million people. Sierra Leone bounds it to the west, Côte d'Ivoire to the east, Guinea to the north and the Atlantic Ocean to the south. The country can be dividing into three physiographic regions: 1) the hilly coastal region; 2) a central plateau ranging from 200 to $250 \mathrm{~m}$ with mountains up to $600 \mathrm{~m}$; and 3) highlands reaching $1380 \mathrm{~m}$ in the north and northeast. According to the Forest Resource Mapping Survey of Liberia (1985) report, about 50\% of the land area, or some 5.5 million hectares, was the forest in the mid-1980s. About 3.88 million 
hectares were productive. As one key sector in Liberia economics, value chain analysis on exports is vital to economic growth and job creation. Liberia January 16, 2006, inaugurated the first elected female president in Africa, Ellen Johnson Sirleaf. As one of her first orders of business, President Johnson Sirleaf restored lawful government control of the forest sector and made clear her goals to govern it clearly with the economy sustainably. The executive order demonstrated the president's commitment to reining in creating a new system for managing the forest sector.

The administration of the forestry sector not only showed a failure to know even the number of logging companies operating in the country. It was also incapable of assessing the total concession area granted for logging operations. During this period, 1989 to 2003, Liberia experienced civil wars, resulting in the deaths of many people and the displacement of millions of Liberians. In the conflict in 1997, the country elected warlord Charles Taylor as President. During his regime, Taylor used the forests of Liberia to fight back and finance his war efforts. Some of the leading logging companies made a significant contribution to Taylor and were actively involved in illegal arms imports for log. At its height, Liberia's timber industry was responsible for widespread abuses of forest inhabitants and destructive logging in concessions covering nearly half of the country. In 2003, the United Nations Security Council recognized the role that logging played in the country's ongoing conflicts and imposed sanctions, banning exports of Liberian timber by member states. In 1976 the report told a total area of 12.7 million sites had been committing Table 3 show the size of timber concessions in Liberia, with low value-added.

\subsubsection{Timber}

Timber production and trade. Liberian statistical information on timber production and mark marketing is highly unreliable. For example, while estimated a total industrial round wood production of $337,000 \mathrm{~m}^{3}$ in 2001 , estimated the volume of log exports that year based on trading-partner reports to be $940,000 \mathrm{~m}^{3}$. According to, total round wood production in 2003 was close to $5.9 \mathrm{million} / \mathrm{m}^{3}$, almost $95 \%$ of which was fuelwood. Over the past decade, a lot of money, media, and political will have invested in efforts to control and regulate formal logging concessions and timber exports. Apart from the 60 cent tax on planks and the yet-to-be passed 2012 Chainsaw Milling Regulation, the informal timber sector

Table 3. Timber production purposes See table below.

\begin{tabular}{cc}
\hline In 1976 (rounded) & Area (millions) \\
\hline Total concession area under Timber Concessions & 8.7 \\
Option areas for Timber Concessions & 1.9 \\
Other areas in use & 0.7 \\
Estimated timberland under Agricultural Development Contract & 1.5 \\
Total & 12.7 \\
\hline
\end{tabular}

(Source: Justification of the Budget of the Forestry Development Authority. 
has developed without the oversight of government regulation. Similarly, international donors and local N.G.O.s have had limited to no impact on shaping the chainsaw milling industry in Liberia.

\subsubsection{Furniture}

October 21, 2016: President Ellen Johnson Sirleaf has toured a Chinese-aided Bamboo \& Rattan Weaving and Vegetables Planting Projects, a "Technological Cooperation between the Governments of Liberia and the People's Republic of China", aimed at making unskilled youths marketable and skilful as an "Element of Sustainability". According to an Executive Mansion release, President Sirleaf made the statement on Friday, October 21, 2016, at the Ministry of Youth and Sports China-Aided Bamboo Furniture Production, Rattan Weaving and Vegetable Planting Exhibition Program at the Samuel Kanyon Doe Sports Complex Community in Paynesville City, Montserrado County. "China has done quite a few things for Liberia, but this one is an element of sustainability," President Sirleaf said. She recommended that Liberia have a group of people providing jobs for themselves. Some of the students graduating from the training use Liberia Bamboo and Cane to weave living and dining room sets. President Sirleaf said the training of these people wouldgive the need for the Government of Liberia to provide for the needs of other Liberians. She said by this, and it means that these Bamboo and Rattan Furniture-making processes in Liberia and Liberians, using Liberian natural resources, will help the Government cut down on the importation of furniture into the country. The Liberian leader said the production of these things would cut down costs and encourage other unskilled Liberians to go into the process aimed at sustaining their livelihood. President Sirleaf used the occasion to call on the Chinese authorities to go one step further by making the bamboo and rattan weaving and vegetable project competitive to compete with those exporting furniture from overseas to make those produced in Liberia marketable.

Earlier, making remarks at the touring ceremony, Chinese Ambassador to Liberia, Zhang Yue, said, "Agriculture is a critical area in Liberia's economic development." Because of this, Ambassador Zhang said China is trying to help in a meaningful way in this direction. He said, this Bamboo and Rattan Weaving team has expanded its project to the Klay Agricultural \& Vocational Training Center to share agricultural techniques and skills with more youths. Ambassador Zhang acknowledged Liberia is a prosperous country in Bamboo, Rattan, Wood, and other resources. He said making the best use of these renewable natural resources is a big potential and opportunity for the country's economic growth. "This is a good way to boost employment and empowerment of women," Ambassador Zhang noted. He said with such purpose, and the Chinese technical team has been working in Liberia for the past ten years-training local Liberians free. "This is a model capacity project because it helps the Liberian people use Liberian resources to make Liberian products," the Chinese envoy noted. "Our people are here promoting "made in Liberia", made by Liberians and made from Liberia," the Chinese envoy concluded. 


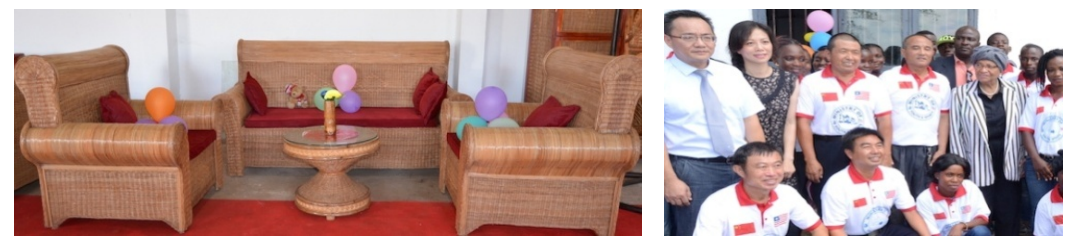

The government of Liberia (G.O.L.) has earmarked millions of United States dollars to improve the country's furniture industry, the Finance Minister has disclosed. He revealed on May 10, 2012, when he met with members and officials of the Liberia Furniture and Carpentry Development Association (LIFCADA) and the Liberia Carpentry Union at Somalia Drive, outside Monrovia. Finance Minister said, millions of dollars will be coming to the furniture sector. Beginning next budget year, 25\% out of every 100 to furniture we buy, 25 pieces must come from Liberian furniture makers; that is now a policy that President Ellen Johnson-Sirleaf has agreed. "We will make sure at the Ministry of Finance that all the government ministries that buy furniture when they come with their vouchers, we'll look for Liberian furniture makers."

\section{Problems in Natural Resource Exports in Liberia}

After World War I, the background of LIBERIA PROBLEM rubber prices on the international markets dropped sharply. These measures became known as the Stevenson Plan and went into force on January 1, 1922. U.S. interests were adversely affected by this protectionist scheme as a penny per pound increase in the price of rubber meant a financial loss of $\$ 8$ million for the U.S. economy (Concession Agreement between the Republic of Liberia and the Liberia Company Signed December 22, 1949). The American economy at this time absorbed approximately two-thirds of the world's rubber output. U.S. industries, notably the automobile industry, needed increasing quantities of this raw material. One American rubber manufacturer became so dissatisfied with the British Government that he introduced "America must grow its rubber". It was Harvey S. Firestone from Akron, Ohio. In West Africa, Firestone found what they wanted. Dependent on the condition that the Liberian Government would also take a \$ 5 million loan from his company. Firestone had won. Moreover, Firestone lent $\$ 5$ million to the Liberian Government through a wholly-owned and, especially for this purpose, created subsidiary, the Finance Corporation of Liberia. In trying to gather information relating to the use of natural resources in Liberia and its impact on the Liberian societies concessions contract system with the study on $\mathrm{Li}$ beria.

Agricultural Sector: (Tables 4-6)

\subsection{Low Value Added in Natural Resource Exports Sector}

Table 5 shows the low value-added on natural resources exports in Liberia. This has caused and is causing problems for the underdevelopment by slowing the development process and human capacity in doing other work. Based on the 
Table 4. Sixty-eight (68) contracts signed by the government of Liberia.

\begin{tabular}{|c|c|c|c|c|c|}
\hline $\begin{array}{l}\text { Sector/Agency } \\
\text { Category }\end{array}$ & $\begin{array}{l}\text { Total Number } \\
\text { of Contracts }\end{array}$ & $\begin{array}{l}\text { Compliant } \\
\text { Contracts }\end{array}$ & $\begin{array}{l}\text { Partially } \\
\text { Compliant }\end{array}$ & Non-Compliant & $\begin{array}{l}\text { Limitation } \\
\text { of Scope }\end{array}$ \\
\hline Number of Contracts in the Agriculture Sector & 4 & - & 3 & 1 & - \\
\hline Agriculture-M.O.A. & 4 & - & 3 & 1 & - \\
\hline Number of Contracts in the Oil Sector & 5 & 2 & 1 & 2 & - \\
\hline Oil-NOCAL Production Sharing Contracts & 5 & 2 & 1 & 2 & - \\
\hline Number of Contracts in the Forestry Sector & 32 & - & - & 32 & - \\
\hline Forest Management Contracts & 4 & - & - & 4 & - \\
\hline Timber Sale Contracts & 5 & - & - & 5 & - \\
\hline Private Use Permits & 23 & - & - & 23 & - \\
\hline Number of Contracts in the Mining Sector & 27 & 4 & 20 & 1 & 2 \\
\hline Exploration Licenses & 14 & - & 13 & - & 1 \\
\hline Class B Mining Licenses & 4 & - & 4 & - & - \\
\hline Gold and Diamond Dealers & 5 & 4 & 1 & - & - \\
\hline Mineral Development Agreements & 4 & - & 3 & - & 1 \\
\hline Total Number of Contracts & 68 & 6 & 25 & 35 & 2 \\
\hline
\end{tabular}

The Liberia Extractive Industries Transparency Initiative (LEITI) is an autonomous agency of the Government established by the LEITI of 2009. Page 13 Moore Stephens LLP. 1. An Act to Ratify the Concession Agreement between the Republic of Liberia and Western Cluster Limited, SesaGao Limited, Bloom Fountain. 2. An Act Approving the Mining Concession Agreement entered into by and between Government of the Republic of Liberia and Bentley International Trading.

Table 5. Companies and location in Liberia.

\begin{tabular}{ccccc}
\hline Company & Date approved & Date printed & $\begin{array}{c}\text { Duration } \\
\text { (years) }\end{array}$ & Location \\
\hline Firestone tire and rubber company & October 2, 1926 & October 10, 1926 & $99+35$ & Harbel, Margibi \\
Cavalla Rubber Corporation & August 2, 2011 & August 17, 2011 & 50 & Maryland \\
Golden Veroleum (Liberia) Inc. & September 1, 2010 & September 2, 2010 & 65 & Multiple \\
Maryland Palm Oil/Decoris & August 2, 2011 & August 17, 2011 & 33 & Maryland \\
Sime Darby Plantation (Liberia) Inc. & July 23, 2009 & July 29, 2009 & 63 & Multiple \\
Cocopa Plantation & January 7, 1949 & January 18, 1949 & 40 & Nimba \\
Sinoe Rubber Corporation & June 5, 1953 & June 19, 1953 & 80 & Sinoe \\
Guthrie Rubber Plantation & May 4, 1963 & May 11, 1963 & 45 & Bomi \\
\hline
\end{tabular}

By the LEITI of 2009. Page 13 Moore Stephens LLP. 1. Iron Ore Appraisal and Mineral Exploration Agreement for the Putu Range between The Republic of Liberia and Mano River Iron Ore (Liberia) Inc. 2. Iron Ore Appraisal and Mineral Exploration Agreement for the Goe-Fantro Range between the Republic of Liberia and B.H.P. Billiton World. 3. Investment Incentives between the Government of Liberia and Buchanan Renewable Energy Sime Darby Liberia Concession Agreement July 23, 2009. 
Table 6. Composition of GDP (percentages).

\begin{tabular}{cccccccccc}
\hline Years & 1978 & 1979 & 1980 & 1987 & 1988 & 1989 & 2003 & 2004 & 2005 \\
\hline Agriculture & $11 \%$ & $10 \%$ & $11 \%$ & $33 \%$ & $28 \%$ & $34 \%$ & $46 \%$ & $52 \%$ & $52 \%$ \\
Rubber & $6 \%$ & $5 \%$ & $6 \%$ & $7 \%$ & $5 \%$ & $7 \%$ & $11 \%$ & $20 \%$ & $21 \%$ \\
Coffee and cocoa & $-/-$ & $-/-$ & $-/-$ & $1 \%$ & $1 \%$ & $1 \%$ & $0 \%$ & $0 \%$ & $0 \%$ \\
Rice & $0 \%$ & $0 \%$ & $0 \%$ & $10 \%$ & $9 \%$ & $10 \%$ & $6 \%$ & $5 \%$ & $6 \%$ \\
Cassava & $0 \%$ & $0 \%$ & $0 \%$ & $5 \%$ & $4 \%$ & $5 \%$ & $10 \%$ & $8 \%$ & $8 \%$ \\
Other & $5 \%$ & $5 \%$ & $5 \%$ & $11 \%$ & $9 \%$ & $11 \%$ & $19 \%$ & $18 \%$ & $17 \%$ \\
Services & $50 \%$ & $49 \%$ & $45 \%$ & $46 \%$ & $46 \%$ & $47 \%$ & $26 \%$ & $24 \%$ & $24 \%$ \\
Government services & $10 \%$ & $10 \%$ & $11 \%$ & $-/-$ & $-/-$ & $-/-$ & $3 \%$ & $3 \%$ & $3 \%$ \\
\hline
\end{tabular}

The Liberia Extractive Industries Transparency Initiative (LEITI) is an autonomous agency of the government established by the LEITI of 2009. Page 13 Moore Stephens LLP 2 Source: C World Bank (1982) C, UNDP (2001) and I.M.F. (various years).

above situation, it is no wonder that economic growth is lacking in Liberia. Let us disuse some bad financial practices in Liberia's natural resources sectors and some recommendations to better Liberia's economic condition. Table 4, for now, the total number of sixty-eight $(68+)$ plus contracts, processes involved in awarding material public concessions, contracts, licenses, Permits and other rights of exploitation of diamond, gold, oil, timber, and agricultural resources of Liberia from July 2009 to December 31, 2011, brought the following results, out of a total number of 68 contracts plus others.

\subsection{Bad Concession Contract Agreement}

Conflicts of interest from past government administrations that affected economic growth continue today; when the bill granting the Firestone Concession was introduced in the National Legislature for approval, it met with tremendous opposition. However, President Charles King, former President Arthur Barclay, Secretary of State Edwin Barclay, and Senator William Tubman staunchly advocated the bill. Interestingly, former President Arthur Barclay and Senator William Tubman was hired by Harvey Firestone as his lawyers in Liberia. Eventually, the bill granting the Firestone Company unprecedented privileges in Liberia has passed. Youth under the age of 25 to 35 will have an excellent opportunity to work and have quality life/living conditions, health care and infrastructure development for the Liberian population. The lack of a value chain and a bad concession contract agreement has caused $80 \%$ of people not to have jobs currently. "The greatest concession of its kind ever made," as Harvey Firestone qualified it, was realized. Open Door Policy without putting a control measure on institutions for the value chain, One of Liberia's oldest disputes, whether or not to make use of foreign capital in the country's development, was revived due to the Firestone Concession Agreement. President King's position was that the government now had an Open Door Policy. His ideas were not uncontested. Nota- 
bly, the exclusive character of the Concession Agreement with Firestone was mentioned by King's opponents to be incompatible with the classical notion of an Open Door Policy.

\subsection{Corruption}

Corruption in the Presidency, Corruption in the Legislature, Corruption among Government Officials, Corruption among Local Government Councilors, Corruption in the Police, Corruption among Judges \& Magistrates, and Corruption Among Tax Officials. Corruption undermined economic growth and development on natural resources exports in Liberia. Liberia is home to globally significant natural resources, and most of its people depend on them for their livelihoods. But the restarting of large-scale extraction of natural resources in the country has proven disastrous for local people, the environment, and efforts to strengthen governance. The natural resources sectors have resoundingly failed to generate the expected revYouth under the age of 25 to 35 will have an excellent opportunity to work and have quality life/living conditions, health care and infrastructure development for the Liberian population. The lack of a value chain has caused $80 \%$ of people not to have jobs currently. Venues, employment, and local benefits due to corruption in Liberia. In contrast, foreign-backed logging companies have routinely ignored reforms and broken laws in collaboration with Liberia's corrupt government officials and policymakers. Past and present Governments are cover with corruption; the President and her Government, to addressing these failures, provide a brief window of opportunity to bring about profound and lasting positive change for Liberia's natural resources, the communities that depend on them, and the broader economy. In a US $\$ 150$ million deal announced at U.N. Climate Summit in New York, the Government of Norway is partnering with the Government of Liberia to halt the destruction of Liberia's rainforest. The deal foresees an end to new logging contracts, more scope for forest-dependent communities to manage their forests and increase protected forest areas. As Liberia contends with a horrifying Ebola outbreak, this partnership will reduce incentives for Liberia to liquidate its forests for cash and help put the country's shattered economy on a more sustainable path towards poverty reduction and environmental protection. "Today's announcement by Liberia and Norway is momentous," said Global Witness Director Patrick Alley. "For decades", Liberia's forests have been more of a curse than a blessing. Timber revenues funded.

Table 7 below explains the income \% by individuals in different sectorspetty trader, employee, contract laborer, charcoal producer, fisheries worker, a rubber tapper, skilled laborer hunter, food crop farmer, cash and food crop, producer, palm oil sellers's, producer, palm oil and food, crop processors, more actions to improve the livelihood of Liberians.

The two sectors are essential to Liberians well-being for economic development, improved infrastructure, growth, job creation, importing new technology, and opening up institutions to the global communities with natural resources. 
Table 7. Livelihood profiles and the composition of income in 2006.

\begin{tabular}{|c|c|c|c|c|c|c|c|c|}
\hline \multirow{2}{*}{$\begin{array}{c}\text { Per capita } \\
\text { Source of income } \\
\text { expenditure } \\
\text { US\$/month }\end{array}$} & \multicolumn{2}{|c|}{ Livelihood profile } & \multicolumn{6}{|c|}{ Source of income } \\
\hline & & $\%$ of $\mathrm{H} . \mathrm{H}$. & Main income & $\%$ & Second income & $\%$ & Third income & $\%$ \\
\hline 17.75 & petty trader & $12 \%$ & petty trade & $81 \%$ & $\begin{array}{l}\text { food crop } \\
\text { production }\end{array}$ & $5 \%$ & contract work & $4 \%$ \\
\hline 17.52 & employee & $5 \%$ & $\begin{array}{l}\text { salary from } \\
\text { employer }\end{array}$ & $75 \%$ & petty trade & $12 \%$ & $\begin{array}{l}\text { food crop } \\
\text { production }\end{array}$ & $8 \%$ \\
\hline 14.68 & contract laborer & $10 \%$ & contract work & $79 \%$ & petty trade & $6 \%$ & $\begin{array}{l}\text { food crop } \\
\text { production }\end{array}$ & $5 \%$ \\
\hline 14.66 & charcoal producer & $7 \%$ & $\begin{array}{l}\text { charcoal/firewood } \\
\text { production }\end{array}$ & $72 \%$ & $\begin{array}{l}\text { food crop } \\
\text { production }\end{array}$ & $8 \%$ & petty trade & $5 \%$ \\
\hline 14.42 & fisheries worker & $4 \%$ & Fishing & $79 \%$ & petty trade & $6 \%$ & $\begin{array}{l}\text { food crop } \\
\text { production }\end{array}$ & $8 \%$ \\
\hline 13.75 & rubber tapper & $7 \%$ & rubber tapping & $75 \%$ & petty trade & $6 \%$ & $\begin{array}{l}\text { food crop } \\
\text { production }\end{array}$ & $5 \%$ \\
\hline 13.64 & skilled laborer & $3 \%$ & skilled labor & $74 \%$ & petty trade & $8 \%$ & $\begin{array}{l}\text { food crop } \\
\text { production }\end{array}$ & $7 \%$ \\
\hline 13.11 & hunter & $5 \%$ & hunting/trapping & $73 \%$ & $\begin{array}{l}\text { food crop } \\
\text { production }\end{array}$ & $8 \%$ & $\begin{array}{l}\text { food crop } \\
\text { production }\end{array}$ & $4 \%$ \\
\hline 11.84 & food crop farmer & $15 \%$ & food crop production & $74 \%$ & petty trade & $6 \%$ & fishing & $4 \%$ \\
\hline 11.80 & $\begin{array}{c}\text { cash and food crop } \\
\text { producer }\end{array}$ & $6 \%$ & $\begin{array}{l}\text { cash crop } \\
\text { production }\end{array}$ & $62 \%$ & $\begin{array}{l}\text { food crop } \\
\text { production }\end{array}$ & $22 \%$ & $\begin{array}{l}\text { processing } \\
\text { palm oil }\end{array}$ & $5 \%$ \\
\hline 11.20 & $\begin{array}{c}\text { palm oil } \\
\text { sellers/producer }\end{array}$ & $14 \%$ & processing palm oil & $84 \%$ & contract work & $5 \%$ & petty trade & $3 \%$ \\
\hline \multirow[t]{2}{*}{11.00} & $\begin{array}{l}\text { palm oil and food } \\
\text { crop processors }\end{array}$ & $8 \%$ & $\begin{array}{c}\text { processing palm } \\
\text { oil }\end{array}$ & $49 \%$ & $\begin{array}{l}\text { food crop } \\
\text { production }\end{array}$ & $26 \%$ & $\begin{array}{l}\text { cash crop } \\
\text { production }\end{array}$ & $5 \%$ \\
\hline & other & $3 \%$ & other activity & $82 \%$ & petty trade & $6 \%$ & $\begin{array}{l}\text { food crop } \\
\text { production }\end{array}$ & $2 \%$ \\
\hline
\end{tabular}

The corruption of resources management has caused Liberia to have more and political instability. Liberia faces enormous economic development challenges.

\section{Measures and Strategies to Solve Value Chain Exports Problems in Liberia}

This section addresses analysis approaches to use when evaluating economic performance strategy to problem-solving. Generally speaking, it identifies how a value chain of natural resources exports in Liberia to develop economic growth, jobs creation, and infrastructure development analysis must consider financial growth performance from a historical perspective and compare with both industry norms to development. The standpoint of decisions markers and stakeholders may be. It should consider focusing on the value chain in Liberia to ensure its responsibilities to society to provide economic growth and benefits to the people of Liberia. Economic growth is central to economic development because when 
Liberia's country or national income grows, the people benefit. Economic growth implies that Liberia's living conditions and standards will improve the citizens of a particular country. Sound economic policies and circumstances strengthen this, but bad economic policies cripple long-term economic growth. Specifically, two factors that promote economic development are the efficiency of labour and capital intensity. The efficiency of labour relates to how technology is deployed and used by an organization or institution are to increase the amount of output a worker can produce, even with the same amount of capital. Capital intensity is how large a multiple of current productions has been set aside in the form of valuable machines, buildings, and infrastructure to boost workers' productivity, even with the same technology and organization. However, economists have argued that investments that increase capital intensity play a significant role in generating economic growth in Liberia, even more, crucial to economic development. Measures and strategies to solve values chain exports problems in a rich country blessed with many natural resources to pull its small population out of poverty and move it well toward sustainable economic development. Many other countries have exploited their natural resource base with great success-through the value chain. With the current boom in commodity prices, there should be no doubt that this remains the most promising strategy value chain on natural resources exports in Liberia for the foreseeable future. As the limits to growth imposed by the small, poor domestic market are reach, it will be critically important to exploit the virtually unlimited global demand for resource-value added based products. Liberia needs to have a well-focused strategy on institutions creating economy policy on value chain on natural resources in Liberia and human capacities to meet economic development and growth in Liberia. The beginning points in analysis the strengthening legal and institutional as a framework:

- Strengthening the legal and institutional framework.

- Operational and Capacity building.

- Improving the added value chain manufacturing in Liberia.

- Attaching great importance to finding analysis on natural resources.

The survey results were not extrapolating, as there is no definitive source on the exact population of chainsaw millers operating across all counties. However, the consistency of the data and large sample size likely make the results representative of chainsaw milling activities in Liberia. Timber Sales Preliminary Survey a preliminary survey was carried out in timber markets in Monrovia before research activities. Timber markets can be organizing as collectively managed plank fields or independently managed plank depots (Guannu, 2005: p. 57). There are seven plank fields, cooperatively working and organized into independently owned smaller outlets, with 275 outlets. In addition, 97 independent plank depots operate outside of the plank fields. A meeting was with each plank field manager. The objectives were to 1) explain the purpose of the study and ask for permission to survey outlet owners weekly; 2) ascertain the size and organizational structure of the plank field; and 3) help to select a sample of outlets to 
be surveyed throughout the study. Shows a representative sample of the small, medium, and ample outlets and independent plank depots were administered a survey once a week, on the same day. Data was not collected on Saturday, the busiest day, because most businesses make their weekly purchases on that day to avoid overestimating sales.

Diagram 1-Start of Operations of Surveyed Chainsaw Millers

Chainsaw millers started chainsaw milling operations for a variety of reasons. Sixty-two percent of respondents stated that they began because they were previously unemployed, and $15 \%$ sought to increase household income. Other motivations for forming chainsaw milling include reconstruction efforts after the war and encouragement from friends to pit-saw to make "quick money". Several respondents began after dropping out of school. Community members conveyed that chainsaw milling began in their forests to instigate reconstruction efforts and encourage the development of their communities through the construction of buildings and homes. On average, chainsaw milling began in or around community forests in 2006, although several communities reported activities starting as early as 1991 and as recently as 2016. Factors that have facilitated the spread of chainsaw milling, the need to supply domestic demand for timber, and response to reconstruction needs following the civil war are the two leading causes that drove the increase in chainsaw milling. Additional enabling factors have facilitated the rapid spread of chainsaw milling. These include 1) low barriers to entry, 2) the former and current presence of concessions, and 3) the lack of regulatory enforcement. Low Barriers to Entry A chainsaw is the one piece of equipment that is essential to a chainsaw milling operation. Sixty-nine percent of surveyed respondents own the saw(s) that they use. Approximately $40 \%$ of saw owners own more than one saw.

\subsection{Strengthening Legal and Institutional Framework}

We need institutions to promote economic liberalization, judicial reform, and greater public participation in public expenditure decisions without explicitly raising contention issues of corruption and, one hope, without threatening their existing economic relationships. The level of corruption and government quality, where the current governance structure can reform, institutions staff can focus on improvements in readily identifiable output indicators rather than uncertain measures of corruption as measures of success. Liberia needs a successful anti-corruption institution framework to set up a system that addresses the underlying governance economic failures value chain analysis on natural resources exports in Liberia, resulting in lower opportunities for gain and a greater likelihood of sanctions. Thus, programs have to be targeting to Liberia's existing quality of governance. Past experiences of the industrialized world confirm these actions to reduce corruption by introducing technocratic solutions and encouraging a sense of public duty among officials through decentralizing decision-making. Table 8 explains how corruption, implementation, and effect are undermining the economic development of Liberia, with millions of people living in poverty. 
Table 8. Effective anti-corruption institution based on governce quality.

\begin{tabular}{|c|c|c|}
\hline $\begin{array}{l}\text { Incidence } \\
\text { of corruption }\end{array}$ & $\begin{array}{c}\text { Governance } \\
\text { Quality }\end{array}$ & $\begin{array}{l}\text { Priorities of Anti-Corruption Efforts } \\
\text { (Based on Drivers of crime) }\end{array}$ \\
\hline High & Poor & $\begin{array}{l}\text { Establish the rule of law, strengthen } \\
\text { institutions of participation and accountability; } \\
\text { limit government interventions to focus } \\
\text { on the core mandate. }\end{array}$ \\
\hline Medium & Fair & $\begin{array}{l}\text { Decentralization economic policy reforms; } \\
\text { results-oriented management and evaluation; } \\
\text { introduction of incentives for competitive public } \\
\text { service delivery for economic growth. }\end{array}$ \\
\hline Low & Good & $\begin{array}{l}\text { Explicit anti-corruption programs such as } \\
\text { anti-corruption agencies; strengthen financial } \\
\text { management; raising public and } \\
\text { officials awareness no bribery pledges, } \\
\text { big fry fish, etc. }\end{array}$ \\
\hline
\end{tabular}

Source: The researcher system analysis view. Concession Agreement between Government of Liberia and Maryland Oil Palm Plantation. Concession Agreement between the Republic of Liberia and Cavalla Rubber Corporation Signed on January 21, 2011.

\subsection{Improving the Added Value Chain Manufacturing in Liberia}

The priority focuses on policy and institutional measures with investment plans using the findings from the sub-sector studies, policy options, policy interventions, and institutional change, particularly concerning the role of every sector's development through intuitions should govern the process of importing equipment in various sectors. Public policy support for decentralization in all industries and the creation of production to meet societal engagement and investment in every sector will enable Liberians to recreate infrastructure in education, healthcare, skills, and other areas for societal development. The potential contribution of selected commodities and services that will allow Liberian achievement through sustainable food security and income for economic development for employment are essential to Liberia's development. The output is expecting to be policy-relevant.

Value chain analysis describes the activities within and around an institution and relates them to an analysis of the competitive strength of the institutions to create jobs. Therefore, it evaluates which makes value on natural resources each particular activity adds to the institution's products or services. This idea built upon the insight that an institution to develop and create jobs is more than a random compilation of machinery, equipment, people, and money. Only if these things are arrange into systems and systematic activities will it become possible to produce something for which customers are willing to pay the price. Porter argues that the ability to perform particular activities and manage the linkages between these activities is a source of competitive advantage of jobs creation for Liberians (Figure 7). 


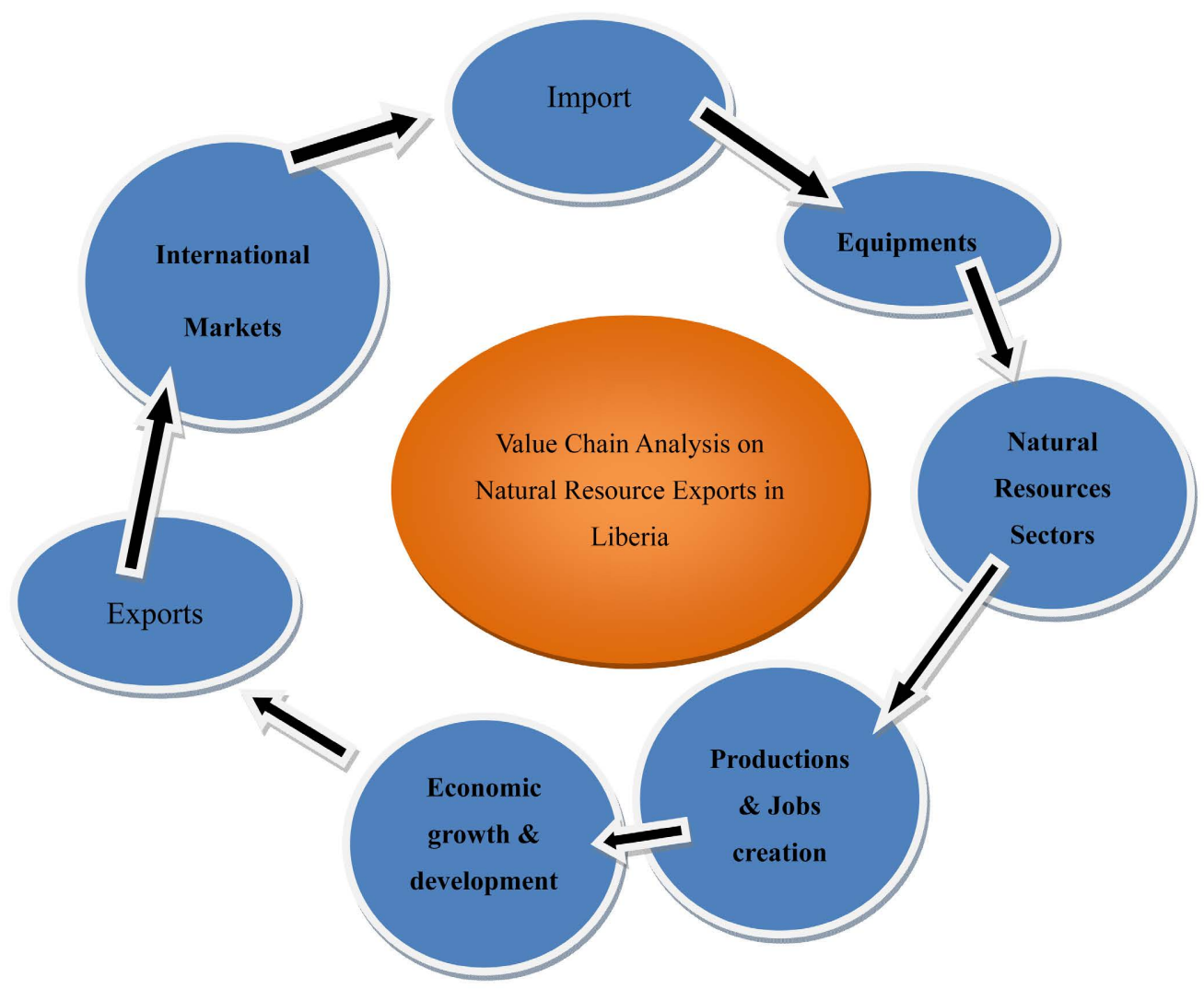

Figure 7. Improving production in Liberia, from raw material exports to products exports. Source: Theory of the researcher view of productions exports in Liberia.

Consensus building through ownership empowerment for employment, throughhout the implementation of Liberia, on building ownership of the whole process to capture the vision of agricultural development as the foundation of economic growth, at all levels that will benefit from the local to international development. As appropriate and feasible, efforts should mobilize institutions and partnerships at different levels (e.g., State, County, Clan, and community). On-job training should also provide experts to each sub-sector team throughout the country. Information data collection and analysis of the annual report is the review and restages for another project, and agriculture has grown and is essential to any growing economy. This significant negative trade balance is a vital factor for Liberia's unsustainable debt position. Value Chain Analysis on Liberia economy growth.

\subsection{Attaching Great Importance to Finding and Analysis on Natural Resources}

Shifting the production chain from outside the country, manufacturing within Liberia to make the value chains domestic production for improved market value is vital for the livelihood of Liberians. This has caused and is causing problems for the underdevelopment, and we need rapid acceleration in the rate of economic progress since 1847s. The questions we virtually ask ourselves. Why is 
economic progress not accelerating in Liberia? Is it possible for a country with resources to be underdeveloped? Not likely, let us look current situation of Liberia signing contract concessions that are not of National interest but individual interest; why the rest of the people suffering, then I asked myself a question? Its a poorly governed or flawed system, or do we not have the right strategy in place? Production of natural resources in Liberia is excellent, opportunities for jobs, and health care, education, and institutions infrastructures will improve. With a peaceful environment to sustain development, we must now make laws for allnatural resources to be processed and produced in Liberia and be exported to other countries. By doing this, we create opportunities for jobs, economic development, and a peaceful environment that will benefit the people of Liberia and give them a sense of ownership that builds consensus and lays the foundation for broad local participation.

For instance, the contribution of food crop production is exceptionally high in the south-eastern counties of Sinoe 35\%, Maryland 29\% and River Gee 26\%. Cash-crop production is predominant in Nimba 15\% and Grand Bassa 10\%. Processing and selling of palm nuts are a crucial source of income and serves as a coping strategy across Liberia, as evidenced by the low expenditure figures of households that depend on this activity but are particularly high in Lofa $37 \%$, River Cess 33\%, and Bomi (27\%). Access to natural resources is essential for coastal and forested areas. Income from fishing contributes to $22 \%$ of the household income in Grand Kru and 14\% in Grand Cape Mount, while trapping and hunting dominate in Grand Gedeh 25\%, River Cess 25\%, Gbarpolu 17\%, and Sinoe $15 \%$. Those areas with large rubber plantations exhibit a dependence on tapping: Margibi22\%, Bomi 15\%, and Maryland 13\%. Selling of charcoal and firewood dominates in Margibi 19\%, Bomi 18\%, and Montserrado due to their proximity to urban households that depend on purchased charcoal as fuel. Montserrado also shows the highest contributions from petty trade/small-scale business, $23 \%$ and salaries from full-time employment (11\%). Finally, contract work is one of the primary income sources in Lofa 19\% and Grand Cape Mount 15\% (Figure 8).

Our food markets are small; a majority of our products are consume within. There is limited marketorientation among farmers who need information on subsistence production for the major food crops in Liberia. Using participatory rural appraisal tools to evaluate harvest by breaking yields into sub-groups based on how the household utilizes crops, we can estimate how much of the total harvest is consuming, sold, gifted, used as payment, preserved as seeds, or spoiled. Across all food crop types, about $5 \%$ are given as gifts to other community members or relatives, and around $2 \%$ are use as payments. The rest are spoiled due to inadequate preservation and storage techniques. Although this study indicates that this is significantly under average, only $7 \%$ of the rice produced sold; however, there are differences across the country, with better-connected counties seeing an increase in market share. Households in Nimba, for instance, sell 17\% 


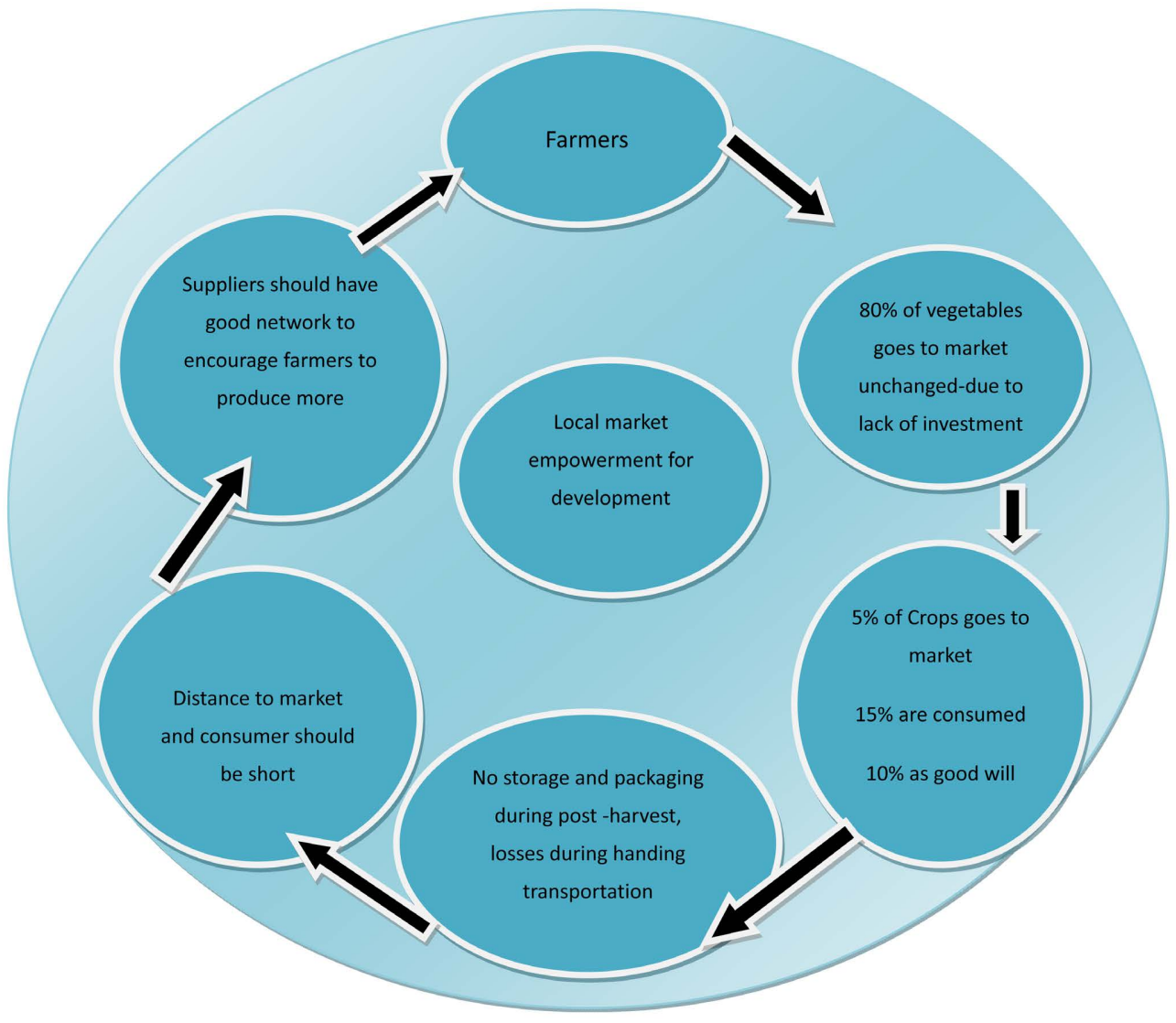

Figure 8. Domestic vegetable value Chain. Source: The researcher is analyzing the farmer's condition from his personal experience in Liberia.

of their rice production, $14 \%$ in Grand Cape Mount, and 11\% in Montserrado. The selling of vegetables dominates in Nimba (72\%), Grand Bassa (67\%), and Montserrado (66\%). Cassavas are also mainly consumed by the producer (57\%), although households are more likely to market cassava than rice (35\% versus 7\%). Cassava is mainly sold in Grand Cape Mount, Montserrado, and River Gee ( $50 \%$ or more). At the same time, $70 \%$ or more- of the cassava are consumed by a producer in River Cess, Grand Kru, Grand Bassa, and Sinoe. The lack of marketsis rarely mention as a priority constraint by households. The value chain analysis, including discussions with stakeholders, illustrated the high degree of wastage along the value chain. Causes include losses due to poor handling, rot, and storage losses. Table 9 explains the strengths and weaknesses of the value chain strategies in Liberia.

The researcher's strategy analysis point of view to improve production in $\mathrm{Li}$ beria Previous studies have suggested that "the swamp development is key in producing a marketable surplus". Nevertheless, the overall experiences of previous agricultural development projects that encouraged swamp rice production provide several helpful lessons, and significant challenges remain. Vegetable growing is the most profitable food crop production activity, with cassava (root crop) show also being relatively good. Perhaps to be expected, Liberia has the 
Table 9. Value chain improving strategies.

\begin{tabular}{|c|c|c|}
\hline The value chain for: & Strengths & Weaknesses \\
\hline $\begin{array}{l}\text { Cereals } \\
\text { (especially rice) }\end{array}$ & $\begin{array}{l}\text { There are two types-upland and lowland. } \\
\text { Most farmers cultivate upland. There is a } \\
\text { strong farming awareness of rice and some } \\
\text { potential for growth in this area. Demand } \\
\text { is high as rice is a staple crop of Liberia. }\end{array}$ & $\begin{array}{l}\text { Processing is by hand, production mainly for home } \\
\text { consumption and little opportunity for surplus as } \\
\text { imports (from China and U.S.A.) are readily available } \\
\text { (even if expensive). The number of harvests achieved } \\
\text { per year is low-currently it is estimated that only one } \\
\text { crop per year is achieved when in fact, this should } \\
\text { be at least Doubled. Productivity per hectare is also too } \\
\text { low, at about } 25 \% \text { that achieved outside Liberia. It is } \\
\text { currently about } 1 \text { M.T./ha. (Based on several } \\
\text { interviews with rice/paddy farmers and verified } \\
\text { by the national consultant on food crops.) }\end{array}$ \\
\hline
\end{tabular}

\begin{tabular}{|c|c|c|}
\hline $\begin{array}{l}\text { Root crops } \\
\text { (the main crop } \\
\text { considered as cassava) }\end{array}$ & $\begin{array}{l}\text { As with rice production, cassava growing } \\
\text { is popular and meets some food security } \\
\text { needs and some cash production needs. } \\
\text { The value-adding potential exists by } \\
\text { converting the commodity, possibly into } \\
\text { bio-fuel or other products such as starch. } \\
\text { Low technology would be a possibility for } \\
\text { Meeting local market demand. }\end{array}$ & $\begin{array}{l}\text { Industrialization of cassava production } \\
\text { and postharvest value-adding is limited and } \\
\text { would require Investment in hardware, training, } \\
\text { and promotion. } \\
\text { Production losses are high from pests } \\
\text { and plant diseases. }\end{array}$ \\
\hline $\begin{array}{l}\text { Vegetables (the main } \\
\text { crops possibly are items } \\
\text { such as bitter ball and } \\
\text { peppers, but it } \\
\text { is difficult to be sure } \\
\text { because of the limited } \\
\text { variety in markets) }\end{array}$ & $\begin{array}{l}\text { A market exists for several vegetables } \\
\text { although items such as tomatoes and } \\
\text { cucumbers, for example, We're not seen } \\
\text { at points of sale. Half of the vegetable } \\
\text { production is for sale in markets, while } \\
\text { the other half is for Home consumption. } \\
\text { The markets are more likely to be urban } \\
\text { centres. } \\
\text { There is the potential to focus on the } \\
\text { vegetable garden and production } \\
\text { systems led by women. }\end{array}$ & $\begin{array}{l}\text { Almost no value-adding is and was observed. } \\
\text { Some vegetable leaves were cut for the consumer } \\
\text { at the Point of sale. Generally poor handling, storage } \\
\text { and packaging caused a significant postharvest loss. }\end{array}$ \\
\hline
\end{tabular}

Source: ${ }^{1}$ Previous studies have suggested that "swamp development is key in producing a marketable surplus". An Act to Ratify the Concession Agreement between the Republic of Liberia and Western Cluster Limited, SesaGao Limited, Bloom Fountain.

high comparative advantage in producing cassava, vegetables for its urban markets, whose reliance on fresh produce is currently only met by domestic production.

\section{Conclusion and Recommendation}

\subsection{Conclusion}

Natural resource capital is essential for economic development in Liberia. There should be a focus on revitalizing the country's exporting value chain engines of growth with an influx of Foreign Direct Investment into key sectors. Liberia's mining, commercial agriculture, forestry, and other industries are operational areas for new industries development. These efforts will pay dividends for economic growth in Liberia. 
Liberia has seen dramatic economic growth before in $1960-70$ past years. At the same time as the engines of the economic growth in other developing countries, natural resources have revived; Liberia also needs to maintain its focus on sustainability by adding value to natural resources exports in Liberia. Liberia has benefited from over USD 16 billion in FDI commitments since the iron ore, forestry, rubber and palm oil. Where is the investment? Investment without a value chain is harmful to economic growth as well to Liberians. Value chains are undeveloped, and markets are inaccessible in Liberia. Rural infrastructure, including roads, is limited and deplorable. Storage, drying, and processing facilities are rare, and food safety and quality control systems remain challenging. It has a rich resource endowment relative to its people; there is no land shortage. Its rainfall and soil make it highly suitable for growing tree crops. The principal export crops produced by small farmers are coffee, oil palm nuts, sugarcane, and fruits. Estimated production in 1999 was coffee, 3000 tons; palm oil, 42,000 tons; and palm kernels, 11,000 tons. Banana production came to 90,000 tons; plantains, 35,000 tons. In 2001, Liberia had an agricultural trade surplus of $\$ 14$ million from 1960 to 1970 . There is a need for legal and social intuitions reforms to improve management of natural resources, transparency and accountability, and inclusive economic development. Substantial progress will be in key sectors like agriculture, forestry, mining, energy, and environment, but reform effort are for ongoing and continuing support for implementation. Liberia needs the development of that sustainable export required for our economy: utilizing natural resources sustainably and efficiently, transforming the economy, and maintaining and enhancing natural capital.

We need significant reforms to shift the tide in Liberia.

\subsection{Recommendation}

To address Liberia's constraints, we need to change our mindset as a people and government from self-interest to the national interest. For development, the Government of Liberia must invest in the agricultural sector, much like the Chinese Government utilized agriculture as key to their growing economic development concerns.

Decision-makers should revisit all concession contracts from 1926 to 2015; all-natural resources by law should be produced in Liberia and exported. We need to add value to the natural resources to create a job for Liberians and improve their living conditions.

We need to invest in the right institutions and skills for the development of Liberia; let us forget the past and come together as Liberians.

Let us give our resources to other countries for beneficial effect. For the past one hundred sixty-seven years (170), we have given our natural resources to other countries, and now we have nothing to show for our economic development. Rural financial Development Programs through commercial banks expand into rural areas as fast as possible to help farmers get assets to loans, in- 
cluding access to a guarantee fund. Still, it is recognizing that attaining significant outreach in rural areas; efforts should also be directed towards setting up a network of Rural and Community Banks in the country. The focus should be on working with farmer groups, cooperatives and associations, development of cooperative and association business, plans to assist in acquiring bank financing should be a priority. Such a project should also require substantial short- and long-term technical assistance.

Each concession should have a working group with representatives from each stakeholder and be responsible for monitoring the fulfilment of the agreement's terms and ensuring that communication lines are open.

\section{Conflicts of Interest}

The author declares no conflicts of interest regarding the publication of this paper.

\section{References}

Addison, T. (2003). Africa's Recovery from Conflict: Making Peace Work for the Poor U.N.U. Wider.

Ahmed, R., \& Donovan, C. (1992). Issues of Infrastructural Development: A Synthesis of the Literature. IFPRI.

An Act Ratifying the Amended and Restated Concession Agreement between G.O.L. and Firestone Liberia Inc.

An Act Ratifying the Amendment to the Mineral Development Agreement (M.D.A.) between The Government of the Republic of Liberia (The Government) and Mittal Steel Holding A. G. and Mittal Steel, August 17, 2005.

Anderson, G. W., Vandervoort, C. G., Suggs, C. M., \& Clapp-Wincek, C. (1982). Rural Roads African Historical Dictionaries Series. Scarecrow Press, 1985.

Barrett, C. B., Reardon, T., \& Webb, P. (2001). Nonfarm Income Diversification and Household Livelihood Strategies in Rural Africa: Concepts.

Block, S., \& Timmer, P. (1994). Agriculture and Economic Growth: Conceptual Issues and the Kenyan Experience. Harvard Institute for International Development.

Boley, G. E. S. (1983). Liberia: The Rise and Fall of the First Republic. MacMillan Publishers.

Bravo-Ortega, C., \& Lederman, D. (2005). Agriculture and National Welfare around the World: Causality and International Heterogeneity since 1960. World Bank Policy Research Working Paper Series 3499. https://doi.org/10.1596/1813-9450-3499

Cassell, C. A. (1970). Liberia: The History of the First African Republic. Fountainhead Publishers, Inc.

Columbia University Press, 1961; reprint, New York: Octagon Books, 1980.

Concession Agreement between the Government of Liberia and the Maryland Oil Palm Plantation August 2, 2011.

Concession Agreement between the Republic of Liberia and the Liberia Company Signed December 22, 1949.

Guannu, J. S. (2005). Liberian History up to 1847 (p. 57). Mineral Exploration Agreement between the Republic of Liberia and Craton Developments Inc.

Johnston, H. (1906). Liberia. Hutchinson. 